\title{
Rancang Bangun Sistem Pengukuran Resistivitas Geolistrik dengan menggunakan Sumber Arus Konstan
}

\author{
Bachtera Indarto, ${ }^{1, *}$ Gusti Rana Fahlevi Sudenasahaq, ${ }^{1}$ Didiek \\ Basuki Rachmad, ${ }^{1}$ Muhammad Hasan Basri, ${ }^{2}$ dan Hasto Sunarno ${ }^{1}$ \\ ${ }^{1}$ Jurusan Fisika, Fakultas Matematika dan Ilmu Pengetahuan Alam, \\ Institut Teknologi Sepuluh Nopember (ITS), Kampus ITS Sukolilo, Surabaya 60111 \\ ${ }^{2}$ Institut Agama Islam Nurul Jadid, JL. KH. Zaini Mun'im, desa, Karanganyar, Paiton, Probolinggo 67291
}

\section{Intisari}

Rancang bangun sistem pengukuran resistivitas geolistrik dengan menggunakan sumber arus konstan telah berhasil dibuat dan dianalisis. Sistem pengukuran resistivitas geolistrik terdiri atas rangkaian konverter boost, sumber arus konstan, dan mikrokontroler sebagai sistem kendali proses pengukuran dan akuisisi data resistivitas geolistrik berupa data resistansi. Sistem akuisisi data menggunakan prinsip hukum Ohm, dengan metode geolistrik Wenner. Sumber arus konstan yang berhasil diimplementasikan pada sistem resistivitas geolistrik yakni arus sebesar $0,1 \mathrm{~mA}$ bekerja pada resistansi $0,4 \Omega$ sampai $2,345 \mathrm{M} \Omega$ dan arus $1 \mathrm{~mA}$ bekerja pada resistansi $0,4 \Omega$ hingga $8,53 \mathrm{k} \Omega$. Serta pada pengukuran resistansi dapat terukur dengan baik pada pengukuran resistasi $33 \Omega$ hingga $470 \mathrm{k} \Omega$.

\begin{abstract}
Design of geoelectric resistivity measurement system using a constant current source has been successfully created and analyzed. Geoelectric resistivity measurement system consists of a boost converter circuit, constant current source, and a microcontroller as the control system in the process of measurement and data acquisition resistivity geoelectric form of resistance data. Data acquisition system using the principles of Ohm's law, the geoelectric method of Wenner. In this study, a constant current source that is successfully implemented on geoelectric resistivity that is a current of $0,1 \mathrm{~mA}$ work on resistance $0,4 \Omega$ until $2,345 \mathrm{M} \Omega$ and a current of $1 \mathrm{~mA}$ is working on $0,4 \Omega$ resistance to $8,53 \mathrm{k} \Omega$. As well as the resistance measurement can be measured by either the resistance measurement $33 \Omega$ to $470 \mathrm{k} \Omega$.
\end{abstract}

KATA KUNCI: Boost konverter, geolistrik-resistivitas, mikrokontroler, sumber arus.

\section{PENDAHULUAN}

Bumi tersusun atas kerak benua dan kerak samudera. Kerak benua tersusun atas bebe-rapa lapisan yang terdiri atas beberapa batuan penyusun dengan karakteristik yang bervariasi. Untuk mengetahui jenis batuan penyusun pada lapisan kerak bumi dapat diketahui dari resistivitas batuan tersebut. Tahanan jenis (resistivitas) merupakan salah satu sifat batuan yang menunjukkan kemampuan batuan tersebut untuk menghantarkan arus listrik [1]. Semakin besar nilai resistivitas suatu batuan maka semakin sulit batuan tersebut menghantarkan arus listrik, begitu pula sebaliknya [2].

Konduktivitas ("daya hantar listrik", DHL) adalah besaran yang menunjukkan banyaknya ion-ion terlarut dalam air yang dapat menghantarkan arus listrik sebesar $1 \mu$ volt pada bidang lapisan metal seluas $1 \mathrm{~cm}^{2}$. Sifat ini dipengaruhi oleh jumlah kandungan yang disebut sebagai ion bebas. Bumi terdiri dari lapisan-lapisan bebatuan dengan nilai resistivitas yang berbeda-beda, sehingga potensial yang terukur dipengaruhi oleh lapisan-lapisan tersebut dan menyebabkan nilai tahanan

\footnotetext{
*E-MAIL: bachtera@physics.its.ac.id
}

jenis yang terukur tergantung pada jarak elektroda. Nilai tahanan jenis yang terukur bukanlah tahanan jenis yang sebenarnya melainkan tahanan jenis semu $\left(\rho_{a}\right)$.

$$
\begin{aligned}
\rho & =\frac{R A}{L} \\
R & =\frac{\Delta V}{I}
\end{aligned}
$$

dengan $\rho=$ resistivitas $(\Omega \mathrm{m}), \mathrm{R}=$ resistansi $(\Omega), \mathrm{I}=$ arus listrik (A), $\mathrm{L}=$ panjang lintasan $(\mathrm{m}), \Delta \mathrm{V}=$ beda tegangan $(\mathrm{V})$.

Salah satu metode yang dapat digunakan untuk mengetahui sifat resistivitas batuan yaitu metode geolistrik resistivitas. Metode geolistrik resistivitas merupakan salah satu metode geofisika yang memanfaatkan sifat resistivitas tanah atau batuan untuk mempelajari keadaan bawah permukaan bumi [3]. Prinsip kerja geolistrik adalah mengukur resistivitas dengan mengalirkan arus listrik kedalam lapisan bawah tanah melalui elektroda arus. Kemudian arus diterima oleh elektroda potensial dengan menganggap bumi sebagai resistor. Metode geolistrik resistivitas menggunakan prinsip hukum Ohm bahwa resistansi suatu bahan berbanding terbalik dengan nilai arus yang mengalir dan berbanding lurus dengan beda potensial. resistansi suatu bahan dipengaruhi oleh resistansi jenis, panjang resistansi dan luas resistansi. 


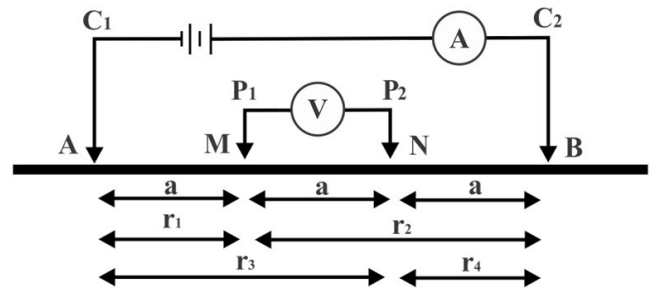

Gambar 1: Elektroda arus dan potensial pada konfigurasi Wenner.

Metode geolistrik resistivitas merupakan metode geolistrik yang mempelajari sifat resistivitas listrik dari lapisan batuan di dalam bumi [3]. Pada metode ini arus listrik diinjeksikan ke dalam bumi melalui dua buah elektroda arus dan dilakukan pengukuran beda potensial melalui dua buah elektroda potensial. Dari hasil pengukuran arus dan beda potensial listrik maka dapat dihitung variasi harga resistivitas pada lapisan permukaan bumi di bawah titik ukur (sounding point). Dalam metode geolistrik dikenal banyak konfigurasi elektroda, diantaranya yang sering digunakan adalah konfigurasi Wenner, konfigurasi Schlumberger, konfigurasi dipol-dipol.

Pada tulisan ini, metode pengukuran resistivitas tanah adalah menggunakan metode konfigurasi Wenner, yang diperkenalkan oleh Wenner (1915). Konfigurasi Wenner merupakan salah satu konfigurasi yang sering digunakan dalam eksplorasi geolistrik dengan susunan jarak spasi sama panjang $\left(r_{1}=r_{4}=a\right.$ dan $\left.r_{2}=r_{3}=2 a\right)$. Jarak antara elektroda arus $\left(\mathrm{C}_{1}\right.$ dan $\left.\mathrm{C}_{2}\right)$ adalah tiga kali jarak elektroda potensial, jarak potensial dengan titik sounding-nya adalah a/2, maka jarak masing-masing elektroda arus dengan titik sounding-nya adalah $3 \mathrm{a} / 2$.

Target kedalaman yang mampu dicapai pada metode ini adalah a/2. Konfigurasi Wenner jarak antara elektroda arus dan elektroda potensial adalah sama $(\mathrm{AM}=\mathrm{NB}=\mathrm{a}$ dan jarak $\mathrm{AN}=\mathrm{MB}=2 \mathrm{a}$ ) seperti yang terlihat pada Gambar 1. Pengukuran resistivitas secara umum dilakukan dengan menginjeksikan arus listrik ke dalam bumi dengan menggunakan dua elektroda arus $\left(\mathrm{C}_{1}\right.$ dan $\left.\mathrm{C}_{2}\right)$, dan pengukuran beda potensial dengan menggunakan dua elektroda tegangan $\left(\mathrm{P}_{1}\right.$ dan $\left.\mathrm{P}_{2}\right)$ [4]. Berdasarkan data harga arus (I) dan beda potensial $(\Delta \mathrm{V})$, dapat dihitung nilai resistivitas semu $\left(\rho_{a}\right)$,

$$
\rho_{a}=k \frac{\Delta V}{I}
$$

dengan $\rho_{a}=$ resistivitas semu $(\Omega \mathrm{m}), \mathrm{k}=$ faktor geometri yang bergantung pada penempatan elektroda.

Sedangkan untuk mencari faktor geometri (k) konfigurasi Wenner dapat dicari dengan persamaan berikut:

$$
k_{w}=\frac{2 \pi}{\left(\frac{1}{A M}-\frac{1}{B M}\right)-\left(\frac{1}{A N}-\frac{1}{B N}\right)}
$$

dengan $\mathrm{k}_{w}=$ faktor geometri konfigurasi Wenner, $\mathrm{AM}=\mathrm{MN}$ $=\mathrm{NB}=\mathrm{a}$. Sehingga faktor geometri untuk konfigurasi Wenner adalah:

$$
\begin{aligned}
& k_{w}=2 \pi a \\
& \rho_{w}=k_{w} R
\end{aligned}
$$

dengan $\mathrm{R}$ adalah besar nilai resistansi yang terukur.

Sumber tegangan ideal adalah elemen sirkuit yang mempertahankan tegangan output tanpa bergantung pada arus beban. Demikian pula, sumber arus ideal adalah elemen sirkuit yang mempertahankan arus yang ditentukan tanpa bergantung pada tegangan keluaran [5]. Sumber arus merupakan sumber yang menyediakan arus konstan tanpa dipengaruhi variasi resistansi beban. Sumber arus dapat dibuat dari kombinasi dioda, transistor (BJT dan Mosfet), dan Op-Amp [6].

Konverter DC-DC berlaku seperti halnya trafo/transformer yang mengubah tegangan $\mathrm{AC}$ tertentu ke tegangan $\mathrm{AC}$ yang lebih tinggi atau lebih rendah. Tidak ada peningkatan ataupun pengurangan daya masukan selama pengkonversian bentuk energi listriknya, sehingga secara ideal persamaan dayanya dapat dituliskan dengan persamaan sebagai berikut:

$$
P_{\text {in }}=P_{\text {out }}+P_{\text {losses }}
$$

Konverter DC-DC dapat dibagi menjadi 2 kategori, yaitu yang terisolasi dan yang tak terisolasi. Kata 'isolasi' disini secara sederhana bermakna adanya penggunaan trafo (isolasi galvanis) antara tegangan masukan dan tegangan keluaran. Beberapa sumber menyebutkan bahwa konverter DCDC yang tak terisolasi dengan istilah direct converter, dan konverter yang terisolasi dengan istilah indirect converter. Konverter boost berfungsi untuk menghasilkan tegangan keluaran yang lebih tinggi dibanding tegangan masukannya, atau biasa disebut dengan konverter penaik tegangan. Konverter ini banyak dimanfaatkan untuk aplikasi pembangkit listrik tenaga surya dan turbin angin. Pada penelitian ini, penulis membuat rangkaian konverter boost dari rangkaian inverter dan rangkaian rectifier. Inverter merupakan suatu rangkaian yang digunakan untuk mengubah sumber tegangan DC tetap menjadi sumber tegangan AC dengan frekuensi tertentu. Rectifier adalah alat yang digunakan untuk mengubah sumber arus bolak-balik (AC) menjadi sinyal sumber arus searah (DC).

\section{METODOLOGI}

Alat dan bahan yang digunakan dalam penelitian ini terdiri dari Atmega 328p, Inverter DC ke AC, Rectifier AC keDC, Baterai $12 \mathrm{~V}-7 \mathrm{Ah}$, LCD $16 \times 2$, kabel, paku-konektor, PCB, batu bata, resistor keramik, baterai Lead Acid 12V 7,2 Ah, accu 12V 32Ah, multimeter, power supply DC.

Sistem perangkat keras terdiri dari beberapa bagian rangkaian meliputi rangkaian konverter boost, rangkaian sumber arus konstan, rangkaian sensor tegangan, rangkaian sensor arus, rangkaian pembalik arah dan rangkaian kontroler sebagai pengukur dan menyimpan data. Sistem perangkat lunak terdiri dari perancangan program dengan menggunakan software Arduino untuk pengolahan hasil pengukuran potensial dan arus serta monitoring hasil resistansi $(\Omega)$ dari pengukuran.

Perancangan dan implementasi perangkat keras meliputi perancangan rangkaian konverter boost, perancangan rangkaian sumber arus konstan, perancangan rangkaian sensor tegangan, perancangan rangkaian sensor arus, perancangan rangkaian penyearah dan perancangan rangkaian kontroler 


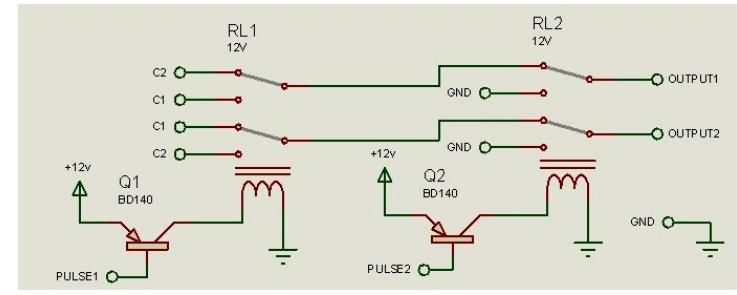

Gambar 2: Rangkaian pembalik arus injeksi.

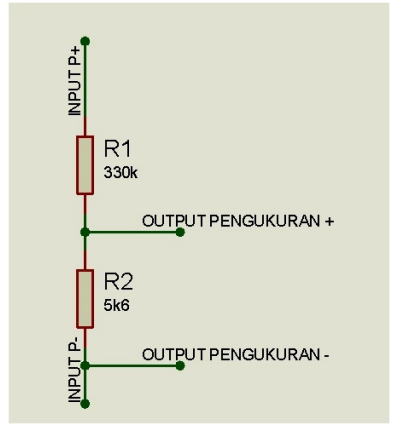

Gambar 3: Perancangan sensor tegangan.

sebagai pengukur dan penyimpan data.

\section{Perancangan konverter boost DC-DC}

Pada pengukuran resistansi dibutuhkan sumber arus yang nantinya akan ditransmisikan pada suatu resistor. Tegangan yang bersumber dari accu perlu dinaikkan agar nilai resistansi yang terhitung dari hasil pengukuran yang didapatkan bernilai besar. Pada penelitian ini menggunakan inverter sebagai penguat tegangan sehingga didapatkan keluaran tegangan AC $220 \mathrm{~V}$ dan kemudian dijadikan menjadi arus DC dengan menggunakan rangkaian rectifier sehingga didapatkan tegangan 250VDC.

\section{Perancangan sumber arus konstan}

Pada penelitian ini menggunakan sumber arus konstan sebagai sumber arus injeksi, sehingga menjaga arus yang

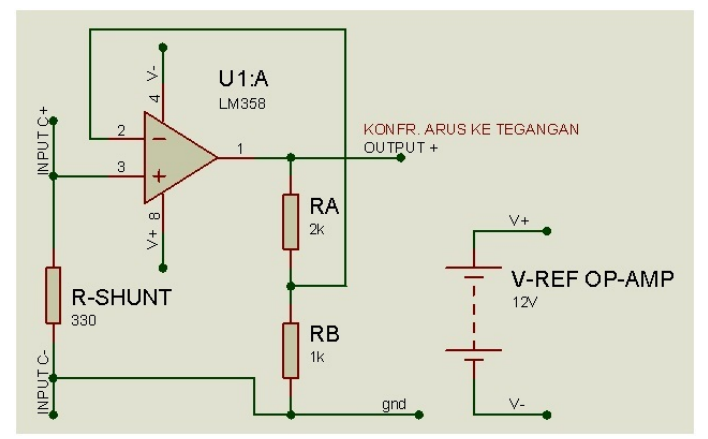

Gambar 4: Perancangan sensor arus. dialirkan tetap konstan tanpa memperhatikan tegangan yang terukur. Rangkaian sumber arus konstan terdiri dari transistor bipolar (npn), op-amp dan resistor. Transistor yang digunakan yaitu MJE13005 dan Op-Amp tipe 1 m358. Penentuan besarnya arus dibagi menjadi 2 bagian yakni konstan $1 \mathrm{~mA}$ dan $0,1 \mathrm{~mA}$.

\section{Perancangan pembalik arah}

Perancangan pengubah arah arus injeksi dirancang seperti pada Gambar 2. Sistem perancangan dibentuk untuk pembuatan titik bidang potensial listrik yang sama besar nilainya, pembalikan arah arus listrik digunakan membandingkan hasil pengukuran potensial pada arah yang berbeda dari proses depolarisasi.

Hal ini juga digunakan untuk mendapatkan perpotongan potensial saat diaplikasikan untuk pengukuran resistansi tanah. Pengukuran potensial menyesuaikan arah aliran arus, artinya pengukuran potensial positif ditempatkan pada arus positif begitu juga dengan sebaliknya.

\section{Perancangan sensor tegangan}

Untuk mengetahui tegangan sumber dan tegangan baterai maka dibutuhkan sensor tegangan. Pada penelitian ini menggunakan sensor tegangan dengan prinsip dasar pembagi tegangan (voltage devider). Sensor tegangan terdiri dari dua resistor yang dirangkai seri dan tegangan referensi diperoleh di titik pencabangan resistor. Hasil tegangan referensi akan dihubungkan ke Arduino UNO sebagai mikrokontroler untuk mengukur dan memonitoring tegangan secara real time. Rangkaian sensor tegangan adalah sebagai berikut, pengukuran potensial 1 disambungkan pada input $\mathrm{P}$ positif dan pengukuran potensial 2 disambungkan pada input $\mathrm{P}$ negatif.

Hasil keluaran sinyal atau output pengukuran positif disambungan pada ADC mikrokontroler sedang-kan titik terendah pengukuran atau output pengukur-an negatif disambungkan pada ground mikrokontroler, seperti Gambar 3.

\section{Perancangan sensor arus}

Pada saat kondisi penginjeksian arus pada resistor, arus merupakan parameter penting karena arus yang akan dialirkan harus tetap konstan sehingga nilai resitansi dapat terukur. Pada penelitian ini, Output sensor arus berupa tegangan sehingga akan terhubungkan langsung ke mikrokontroler, seperti pada Gambar 4 yaitu rangkaian sensor arus.

Sensor arus dipasang secara seri terhadap resistor. Arus input positif disambungkan pada input positif dan arus input negatif disambungkan pada input negatif. Tegangan referensi yang digunakan Op-Amp sebesar 12VDC dengan baterai sebagai sumber tegangannya. Hasil konversi arus ke tegangan akan diolah dengan menggunakan ADC mikrokontroler. 


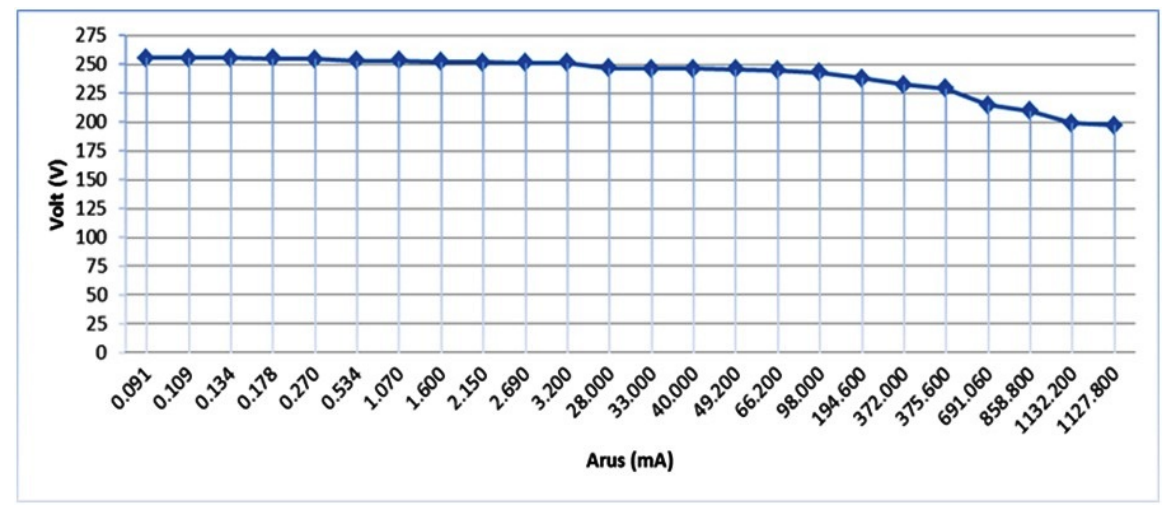

Gambar 5: Hasil pengujian karakteristik konverter boost.

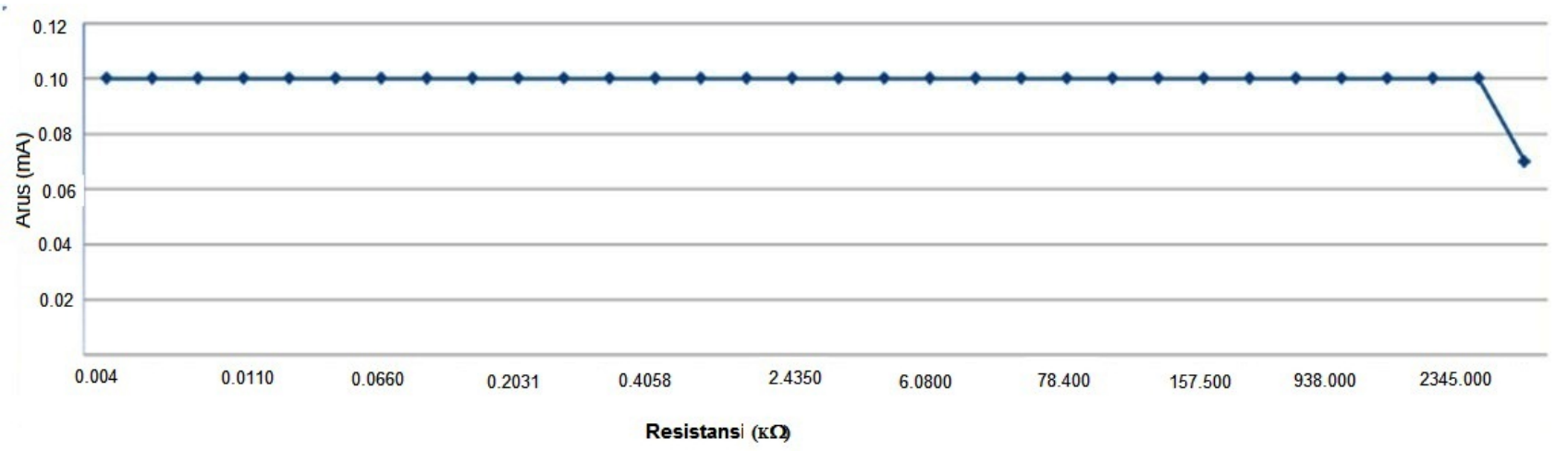

Gambar 6: Grafik hasil uji Sumber arus konstan 0,1 mA.

\section{HASIL DAN PEMBAHASAN}

\section{Morfologi pengujian karakteristik konverter boost}

Pengujian dilakukan untuk mengetahui karakteristik pembebanan konverter boost dengan mengukur tegangan keluaran dan arus beban yang diberikan. Pada pengujian ini pembebanan menggunakan resistor. Pengujian karakteristik konverter boost meliputi pengukuran tegangan open circuit $\left(\mathrm{V}_{o c}\right)$ atau pengukuran tanpa beban yang dilakukan langsung menggunakan voltmeter dan selanjutnya pengukuran dengan beban data yang diambil adalah data tegangan beban yang dipasang paralel dan pengukuran arus beban yang disambungkan secara seri tehadap beban. Tegangan konverter boost menggunakan aki $12 \mathrm{~V} / 32 \mathrm{Ah}$, berdasarkan hasil pengujian yang telah dilakukan didapatkan tegangan dasar atau tegangan open circuit adalah 255VDC. Adapun hasil pengujian karakteristik konverter boost dapat ditunjukkan seperti pada Gambar 5.

\section{Pengujian karakteristik sumber arus}

Nilai resistansi didapatkan dari perhitungan pengukuran tegangan dan arus. Penulis menggunakan sumber arus di mana arus yang dialirkan pada beban akan dijaga konstan. Namun, untuk mendapatkan arus yang konstan tidak luput dari hukum kekekalan energi dimana daya input sama dengan daya output ditambah dengan daya yang terbuang. Pada pengujian sumber arus ini digunakan uji pembebanan dengan menggunakan resistor dari resistansi 0,4 $\Omega$ hingga 2,817 $\mathrm{M} \Omega$. Pengujian ini dibuat konstan menjadi dua bagian $0,1 \mathrm{~mA}$ dan $1 \mathrm{~mA}$.

Hasil karakterisasi sumber arus konstan 0,1 mA ditunjukkan Gambar 6. Pada pengukuran sumber arus konstan 0,1 $\mathrm{mA}$ pembebanan dimulai pada resistansi $0,4 \Omega$ dan tetap konstan hingga resistansi 2,345 $\mathrm{M} \Omega$. Daya beban yang terpakai melebihi daya minimum input oleh karena itu arus tak dapat konstan lebih dari 2,345 $\mathrm{M} \Omega$.

Berdasarkan hukum Ohm, ketika tegangan sumber tegangan adalah 255VDC dengan injeksi arus yang mengalir pada rangkaian tertutup adalah $0,1 \mathrm{~mA}$ maka resistansi maksimum yang dapat terukur adalah $2,550 \mathrm{M} \Omega$, hal ini terukur pada keadaan ideal namun pada kenyataannya masi terdapat daya yang hilang akibat panas maupun dari resistansi kabel. Oleh karena itu pada karakterisasi sumber arus konstan tidak dapat mempertahankan arus konstan pada resistor 2,817 $\mathrm{M} \Omega$. Berdasarkan Gambar 6 dapat disimpulkan bahwa arus konstan $0,1 \mathrm{~mA}$ dapat digunakan untuk mengukur resistansi pada rentang $0,4 \Omega$ hingga 2,345 $\mathrm{M} \Omega$, sedangkan pada pengukuran arus konstan 1mA (Gambar 7) dapat digunakan sebagai pengukuran hingga resistansi $0,4 \Omega$ hingga $8,3 \mathrm{k} \Omega$. 


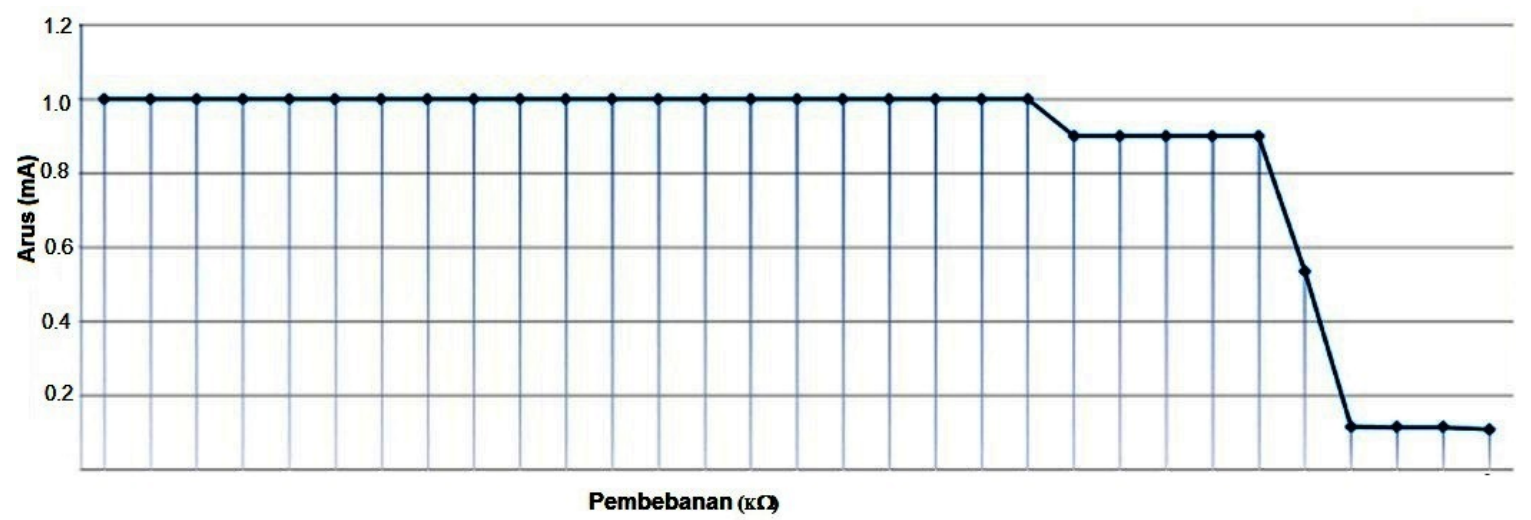

Gambar 7: Grafik hasil uji Sumber arus konstan $1 \mathrm{~mA}$.

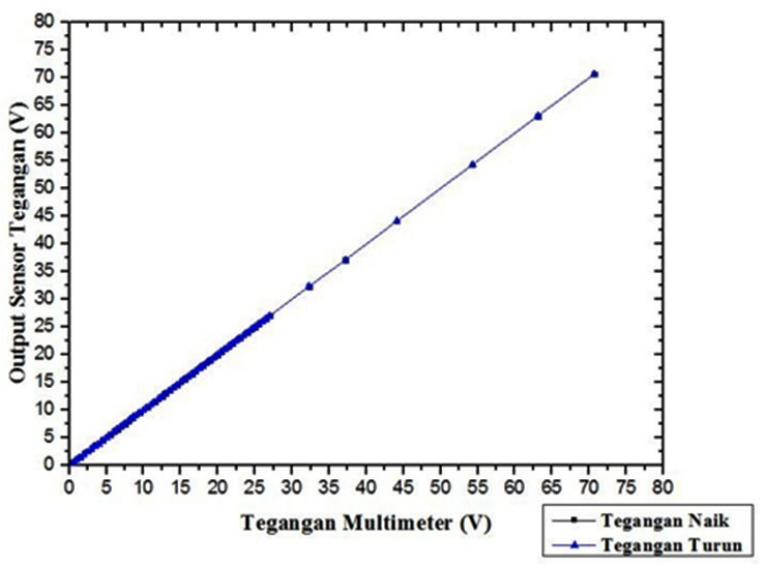

Gambar 8: Hasil pengujian histerisis sensor tegangan.

\section{Pengujian karakteristik sensor tegangan}

Sensor tegangan digunakan untuk mengukur tegangan pada beban. Sensor tegangan yang diimplementasikan menggunakan prinsip pembagi tegangan yang terdiri dari dua resistor dirangkai seri sehingga diperoleh tegangan referensi pada titik percabangan resistor. Tegangan referensi sensor menggunakan tegangan batas mikrokontroler yakni maksimal pada tegangan $+5 \mathrm{~V} \mathrm{DC}$.

Tegangan yang terukur berupa sinyal analog akan dikonversikan ke bentuk binner. Mikrokontroler yang digunakan menggunakan 10 bit yang nilai pengukuran yang diterima diubah ke nilai digital yang maksimum 1023. Stabilitas sensor tegangan dapat diamati dari hasil kurva histerisis seperti pada Gambar 8.

Arus listrik yang dialirkan pada beban harus dijaga konstan salah satu tujuannya memperkecil variabel pengukuran. Gambar 9 merupakan hasil kalibrasi sensor arus dengan menggunakan multimeter pengukuran kalibrasi dimulai pada arus $0,03 \mathrm{~mA}$ hingga 1,04 mA. pada saat kalibrasi sensor tidak dapat mengukur pada arus $0,75 \mathrm{~mA}$ hingga $0,79 \mathrm{~mA}$ dan
0,84 mA hingga 0,88 mA. Hal ini terjadi karena perubahan nilai analog ke digital pada mikro, namun pada dasarnya nilai pengukuran yang dihasilkan sama dengan yang terukur menggunakan multimeter. Hasil pengukuran yang dihasilkan pada multimeter tidak dapat terukur pada ketelitian tiga angka dibelakang koma, sedangkan pengukuran ketelitian pada mikro dapat terukur tiga angka di belakang koma, sehingga data yang didapatkan mendekati kesamaan pada ketelitian dua angka dibelakang koma.

Pada Tabel I merupakan hasil uji prototipe pada pengukuran resistansi yang dibandingan dengan hasil perhitungan yang didapatkan dari pengukuran arus dan tegangan serta nilai resistansi yang diukur dengan menggunakan alat tigre resistivity meter. Pengujian ini dilakukan tiga kali pengulangan kemudian dihitung simpangan pada masing-masing pengukuran. Acuan pengukuran terletak pada data perhitungan. Dari data tersebut pada prototipe mengalami simpangan pada pengukuran resistansi $0,47 \Omega$ dan $3,9 \Omega$. Hal ini dapat terjadi karena penurunan kwalitas dalam pengukuran sensor. Pada standar pengukuran mikro yang dapat terukur minimal adalah 4,8 $\mathrm{mV}$ untuk satu bit yang didapatkan dari $5 \mathrm{~V}$ sebagai tegangan referensinya dalam skala 10 bit. Dari tegangan pengukuran yang kecil dalam skala milivolt mengakibatkan sensor tegangan tidak dapat bekerja secara maksimal. Sehingga untuk mengatasi masalah ini dapat diselesaikan dengan meningkatkan skala bit pengukuran pada sensor atau dengan penginjeksian arus yag lebih besar.

Penerapan pada hukum Ohm yang ada di mana tegangan pada resistor berbanding lurus arus listrik yang mengalir pada resistor, sehingga untuk meningkatkan tegangan pengukuran arus yang diinjeksikan lebih besar dari batas minimum pengukuran sensor agar dapat terbaca dengan baik. Dari hasil pengujian yang telah ada prototipe dapat bekerja dengan baik pada pengukuran resistansi $33 \Omega$ hingga $470 \mathrm{k} \Omega$. 


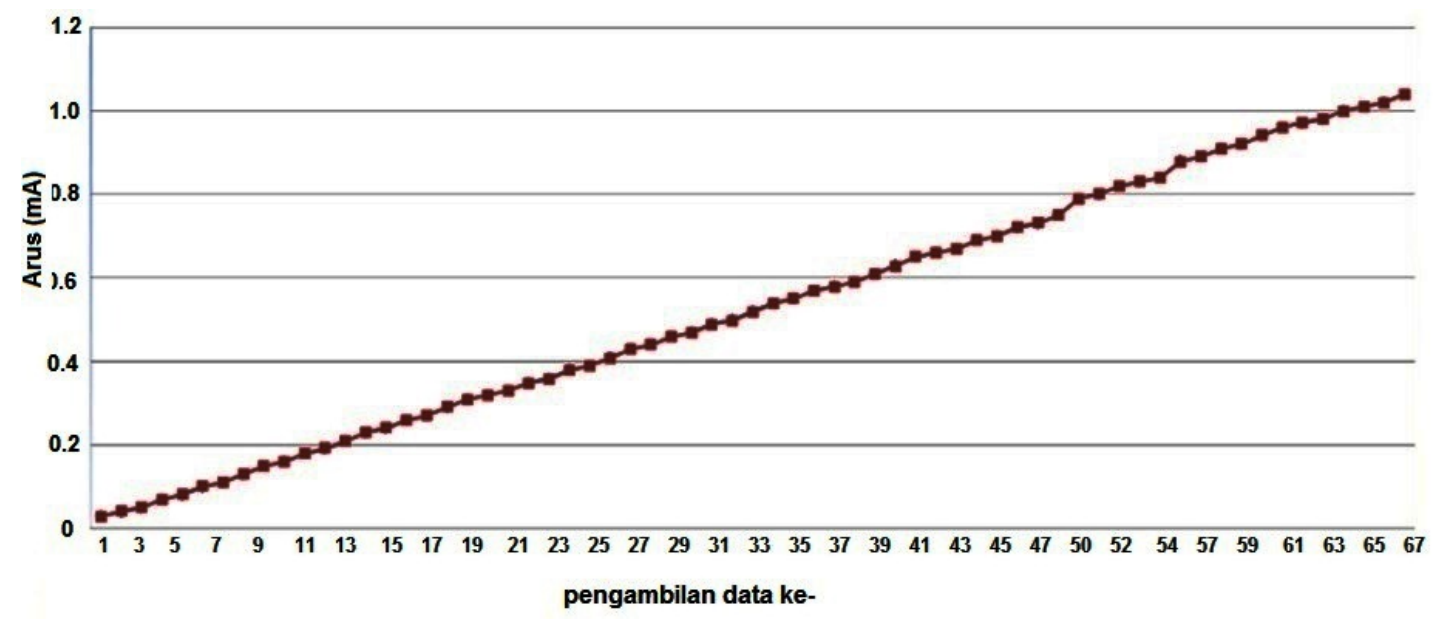

Gambar 9: Hasil pengujian karakterisasi sensor arus.

TABEL I: Pengaruh variasi seting rapat fluks pada gap udara terhadap fluks pada inti, magnetomotansi dan arus listrik.

\begin{tabular}{|c|c|c|c|c|c|c|c|c|c|c|}
\hline \multirow[t]{2}{*}{ No } & \multirow{2}{*}{$\begin{array}{l}\text { Nama } \\
\mathrm{R}(\Omega)\end{array}$} & \multicolumn{2}{|c|}{ Perhitungan } & \multirow{2}{*}{$\begin{array}{l}\text { Standar } \\
\text { Deviasi }\end{array}$} & \multicolumn{2}{|c|}{ R Trigger } & \multirow{2}{*}{$\begin{array}{l}\text { Standar } \\
\text { Deviasi }\end{array}$} & \multicolumn{2}{|c|}{ R prototipe } & \multirow{2}{*}{$\begin{array}{l}\text { Standar } \\
\text { Deviasi }\end{array}$} \\
\hline & & $\mathrm{R}(\Omega)$ & rata-rata & & $\mathrm{R}(\Omega)$ & rata-rata & & $\mathrm{R}(\Omega)$ & rata-rata & \\
\hline \multirow[t]{3}{*}{1} & 0,47 & 0,82 & 0,82 & 0 & 0,47 & 0,46 & 0,0052 & 0,78 & 0,79 & 0,0189 \\
\hline & & 0,82 & & & 0,46 & & & 0,76 & & \\
\hline & & 0,82 & & & 0,46 & & & 0,81 & & \\
\hline \multirow[t]{3}{*}{2} & 3,9 & 4,23 & 4,23 & 0 & 3,94 & 3,94 & 0 & 3,13 & 3,19 & 0,0737 \\
\hline & & 4,23 & & & 3,94 & & & 3,27 & & \\
\hline & & 4,23 & & & 3,94 & & & 3,16 & & \\
\hline \multirow[t]{3}{*}{3} & 33 & 33,70 & 33,70 & 0 & 32,57 & 32,64 & 0,0577 & 33,5 & 33,5 & 0 \\
\hline & & 33,70 & & & 32,67 & & & 33,5 & & \\
\hline & & 33,70 & & & 32,67 & & & 33,5 & & \\
\hline \multirow[t]{3}{*}{4} & 120 & 121,57 & 121,57 & 0 & 121,7 & 121,7 & 0 & 124 & 124 & 0 \\
\hline & & 121,57 & & & 121,7 & & & 124 & & \\
\hline & & 121,57 & & & 121,7 & & & 124 & & \\
\hline \multirow[t]{3}{*}{5} & 270 & 288,37 & 288,37 & 0 & 272,6 & 272,6 & 0 & 288 & 288 & 0 \\
\hline & & 288,37 & & & 272,6 & & & 288 & & \\
\hline & & 288,37 & & & 272,6 & & & 288 & & \\
\hline \multirow[t]{3}{*}{6} & 470 & 476,92 & 476,92 & 0 & 472,5 & 472,5 & 0 & 476 & 476 & 0 \\
\hline & & 476,92 & & & 472,5 & & & 476 & & \\
\hline & & 476,92 & & & 472,5 & & & 476 & & \\
\hline \multirow[t]{3}{*}{7} & 1200 & 1240,00 & 1240 & 0 & 1235 & 1235 & 0 & 1240 & 1240 & 0 \\
\hline & & 1240,00 & & & 1235 & & & 1240 & & \\
\hline & & 1240,00 & & & 1235 & & & 1240 & & \\
\hline \multirow[t]{3}{*}{8} & 10000 & 10333,33 & 10333,33 & 0 & 9894 & 9894 & 0 & 9800 & 9800 & 0 \\
\hline & & 10333,33 & & & 9894 & & & 9800 & & \\
\hline & & 10333,33 & & & 9894 & & & 9800 & & \\
\hline \multirow[t]{3}{*}{9} & 470000 & 472560,98 & 472561 & 0 & tidak & dapat & terukur & 46940 & 46940 & 0 \\
\hline & & 472560,98 & & & & & & 46940 & & \\
\hline & & 472560,98 & & & & & & 46940 & & \\
\hline
\end{tabular}

\section{SIMPULAN}

Berdasarkan hasil pengujian dapat disimpulkan bahwa implementasi sumber arus konstan pada rancang bangun sistem pengukuran geolistrik resistivitas meter berhasil dilakukan dengan tiga tahapan kerja utama yakni penaik tegangan (konverter boost) dari tegangan $12 \mathrm{~V}$ menjadi $250 \mathrm{~V}$, sistem kontrol sumber arus konstan 0,1 mA dan $1 \mathrm{~mA}$, serta sistem pengukuran (tegangan dan arus) dan pengolahan data. 


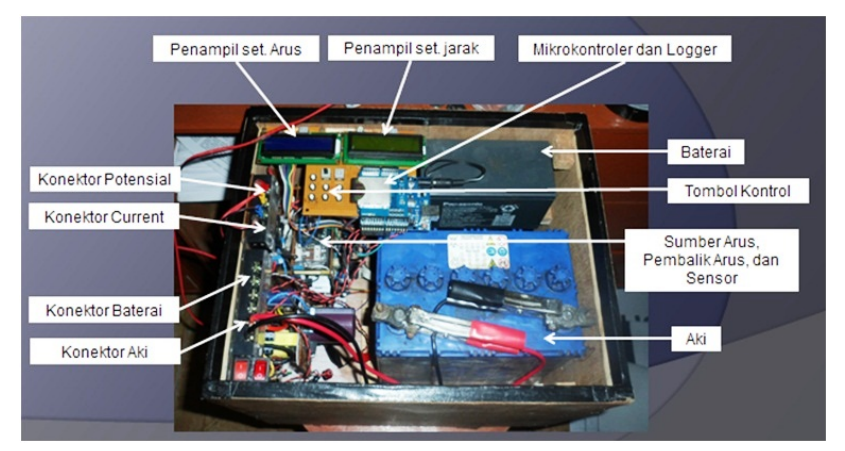

Gambar 10: Prototipe sistem pengukuran geolistrik resistivitas meter dengan menggunakan sumber arus konstan.

[1] S.H. Ward, Resistivity and induced polarization methods, in Geotechnical and Environmental Geophysics (Vol. 1, S.H. Ward (ed.), Soc. of Expl. Geophys, 1990).

[2] H. Grandis, Diktat Kuliah Geo-Elektromagnet (Departemen Geofisika, FIKTM, Institut Teknologi Bandung, Bandung, 2006).

[3] L. Hendrajaya, dan A. Idam, Geolistrik Tahanan Jenis (Laboratorium Fisika Bumi, Jurusan Fisika FMIPA ITB, 1990).
[4] J. Milsom, Field Geophysics, The Geological Field Guide Series (3rd Edition, John Wiley \& Sons, West Sussex, 2003)

[5] J.W. Nilson, and S.A. Riedel, Electric Circuits (Eighth Edition, New Jerscy: Pearson Education Inc., 2008).

[6] L.T. Harrison, Current Sources and Voltage References: A Design Reference for Electronics Engineers (Newnes, 2005) 